\title{
E-WOM as Moderating Effect of Facility and Destination Development to Decision Visiting Perak Island Tourists
}

\author{
Yuni Astuti ${ }^{1}$, Niken Purbasari ${ }^{2}$, Tita Deitiana ${ }^{3}$, Joko Sugiharjo ${ }^{4}$, Sitti Rakhman ${ }^{5}$ \\ 1,4,5 Universitas Mercu Buana, Indonesia, ${ }^{2,3}$ STIE Universitas Trisakti, Indonesia \\ yuniastuti@mercubuana.ac.id,npurbasari@stietrisakti.ac.id \\ Manajemen, Fakultas Ekonomi dan Bisnis Universitas Mercu Buana, Indonesia
}

\begin{abstract}
Pulau Perak Pulau Seribu Jakarta, has the appeal of soft white sand beaches and turquoise sea water, mangroves and other trees are no less beautiful. From the coast of Perak, the island can see directly to the sea floor, not having to dive, with white sand and coral rocks scattered at the bottom. Based on data from the Central Java Pulau Seribu Statistics Agency 2018, local tourist arrivals to Perak Island are 30 people per month and the number of foreign tourists is 5 people per month, indicating the still low number of tourist visits to Perak Island compared to tourist arrivals in the Pulau Seribu which reached 13,792 people per month. To overcome this problem, it is necessary to increase the attractiveness of tourist destinations and the development of facilities on Perak Island. The purpose of this study is to analyze the Electronic Word of Mouth (E-WoM) as moderating the development of facilities and destinations for tourists visiting the Perak Island Pulau Seribus, Jakarta. The population in this study was Perak Island tourists, with a sample of 100 tourists. The sampling method uses random sampling. Data collection methods using survey methods with research instruments is a questionnaire. The data analysis method uses Structural Equation Model-Partial Least Square 3.0 (SEM-PLS). Based on the results of data analysis it was found that the destination has a positive effect on the decision of visiting tourists, E-WoM has a positive effect on the decision of visiting tourists, E-WoM can increase the Destination of tourist visiting decisions. E-WoM cannot improve the development of facilities on tourist visiting decisions. Researchers suggest increasing the diversity of souvenirs that are typical in tourist areas. Improve the places that tourists must visit and the diversity of recreation that tourists can do. Also increases the availability and accuracy of information clearly.
\end{abstract}

Keywords: visit, destination, E-WOM, facilities, moderation

DOI: $10.7176 /$ JTHS/49-06

Publication date: July $31^{\text {st }} 2020$

\section{INTRODUCTION}

In the Pulau Seribus there are many small islands, one of which is the Perak island. Perak Island is one of the islands that is uninhabited and still natural but very interesting and has the potential to be used as a natural tourist location because it stores the beauty of white sand that stretches plus the blue ocean. This location is often a mandatory destination for travelers who stay on Harapan Island or Pulau Putri because of its proximity (Abdila, 2015). Pulau Perak has a land area of around 3.06 hectares. Not only white sand and soft beaches and turquoise sea, mangroves and trees are no less interesting to simply take pictures and enjoy the view. From the shore of the island of Perak you can see the sea floor directly with white sand and coral rocks scattered at the bottom can be seen directly from the surface without having to dive (Alpiah, 2019).

Based on data from the Central Bureau of Statistics of the Pulau Seribus 2018, the number of local tourists visiting Perak Island is 30 people per month and the number of foreign tourists is 5 people per month, indicating the low number of tourist visits to Perak Island compared to visits to Pulau Seribu which per month reaches 13,792 people per month. To overcome this problem, it is necessary to increase the attractiveness of tourist destinations and the development of facilities in Pulau Perak. The purpose of this study is to analyze the Electronic Word of Mouth (EWoM) as moderating the development of facilities and destinations towards the decision of tourists visiting the Pulau Perak Island Pulau Seribus Jakarta

In research in developing countries, it is reviewed that tourist visiting decisions are influenced by facility development. In Pretoria, South Africa, Nthebe and Seart (2017) examined the development of tourist facilities for the intention of business tourists to visit tourist attractions. In Indonesia, some researchers also study the development of facilities for tourist visiting decisions, including Alpiah (2019), Singgih (2017), Wijayanti (2012), Purba and Simaranta (2018). It can be concluded that the development of facilities is still a problem in increasing tourist visits. 
In addition to facility development, several studies on tourist visiting decisions in several countries are influenced by tourist destinations (Ambarwati, 2019, Margaretith and Altje, 2016; Wartini, 2018 and Prayogo, 2016; Boley and Green, 2016; Qing Chi and Hailin Au, 2018; and Fang Meng et all, 2018) which states that the object of natural, cultural attraction influences the decision of tourists visiting. According to Suwantoro (2014) tourist objects and attractions are grouped into 3 parts: 1) Natural tourism objects and attractions, 2) Tourist objects and attractions, 3) Tourist objects and attractions of special interest, which still need to be investigated.

Besides the development of facilities and destinations, several studies of tourist visiting decisions are influenced by E-WoM (Singgih, 2017), Abubakar et all (2017) and Rizal et all (2018) which states that E-WoM has proven to influence tourist visiting decisions, as well The effect of information quality and the quality of electronic services can drive tourist visiting decisions. According to Wardiyastuti (2017) E-WoM as a form of communication that develops from WoM electronically or with the use of the internet, which is better than personal selling or conventional advertising where consumers use the internet to share experiences after using products or services, or consumers can take advantage of people's experiences others to make a purchase.

Based on the above research phenomena, it is interesting to analyze E-WOM as the Moderating Effect of Facility and Destination Development Against the Visiting decision of Pulau Perak Pulau Seribus, Jakarta.

\section{CONCEPTUAL FRAMEWORK AND DEVELOPMENT OF HYPOTHESES}

\section{a. Relationship between Facility Development and Tourist Visit Decision}

The decision to visit a tourist is a travel activity carried out by someone with the purpose of recreation and entertainment and has preparation about travel activities. According to Edward Inskeep (1991) in Sarim \& Wiyana (2017), facilities are Accommodation, Restaurant, Shopping, Public Facilities. According to Ismayanti (2010) variations of tourists can be viewed from various approaches including psychography, socio-economics, geography and travel patterns. The essence of tourism is to travel both for education and training or for leisure or recreation

The theory of interest in visiting is analogous to buying interest, such as research conducted by Albaraq (2014) which states that the interest in visiting tourists is the same as the purchase interest of consumers. According to Kotler and Susanto (2000) that interest as an impulse, is a strong internal stimulation that motivates action, where this impulse is influenced by stimulus and positive feelings about the product. Based on the research results of Zabkar et al (2017), Nowacki (2009) and Nachyun et all (2015) circumstances, the quality of tourist attractions influences the decision of tourists to visit. Based on the description, the following hypotheses can be proposed:

H1: Facility development has a positive effect on tourist visiting decisions

b. Relationship between Destinations and Tourist Visit Decisions

According to Yoeti (2010). Tourist attractions, in a tourist destination there are basically three things that are always a question of tourists when visiting, namely: 1. Something to see, 2. Something to do and 3. Something to buy. According to Suwantoro (2014) tourist objects and attractions are grouped into 3 parts: 1) Natural tourism objects and attractions, 2) Tourist objects and attractions, 3) Tourist objects and attractions of special interest. Meanwhile, according to the results of research by Boley and Green (2016), Qing Chi and Hailinu (2008), Devesa, et all (2010) and Fang Meng et all (2008) which state that objects of natural, cultural and motivational attraction influence tourist decisions. Based on the description, the following hypotheses can be proposed:

$\mathrm{H} 2$ : The destination has a positive effect on tourist visiting decisions

\section{c. E-WOM Relations and Tourist Visit Decisions}

Electronic Word of Mouth (E-WoM) is a different activity in actual reality. E-WoM according to Wardiyastuti (2017) as a form of communication that develops from WoM electronically or with the use of the internet, which is better than personal selling or conventional advertising where consumers use the internet to share experiences after using products or services, or consumers can take advantage of people's experiences others to make a purchase.

The results of Abubakar et all (2017) and Rizal et all (2018) research stated that the effect of information quality and electronic service quality on satisfaction is important, which can drive tourist visiting decisions. Based on the description, the following hypotheses can be proposed:

H3: E-WOM has a positive effect on tourist visiting decisions 


\section{d. E-WOM Relationship as Moderator of Facility Development Towards Tourist Visit Decisions}

According to Al Hasan and Setyaningtyas in their study (2015) said e-WoM included caring for others, expressing positive feelings, tourist publications about the tourist environment, promotional media, expressing negative feelings, quality of service, availability of clear information and accuracy, saving costs and open opportunities.

Based on research results Sunny Sun et al (2019), Ariany and Wandebory (2016) and Abubakar (2016) which stated that the attributes of tourism and electronic products by word of mouth influence the decision of prospective visitors to come to tourist attractions. Based on the description, the following hypotheses can be proposed:

H4: E-WOM can enhance the development of facilities on tourist visiting decisions.

e. The E-WOM relationship as a destination moderator for tourists visiting decisions

According to Suwantoro (2014) tourist objects and attractions are grouped into 3 parts: 1) Natural tourism objects and attractions, 2) Tourist objects and attractions, 3) Tourist objects and attractions of special interest. Meanwhile, according to the results of research by Boley and Green (2016), Qing Chi and Hailinu (2008), Devesa, et all (2010) and Fang Meng et all (2008) which state that objects of natural, cultural and motivational attraction influence tourist decisions.

Based on research results Sunny Sun et al (2019), Ariany and Wandebory (2016) and Abubakar (2016) which stated that the attributes of tourism and electronic products by word of mouth influence the decision of prospective visitors to come to tourist attractions. Based on the description, the hypothesis can be submitted as follows

Figure 1 : conceptual framework

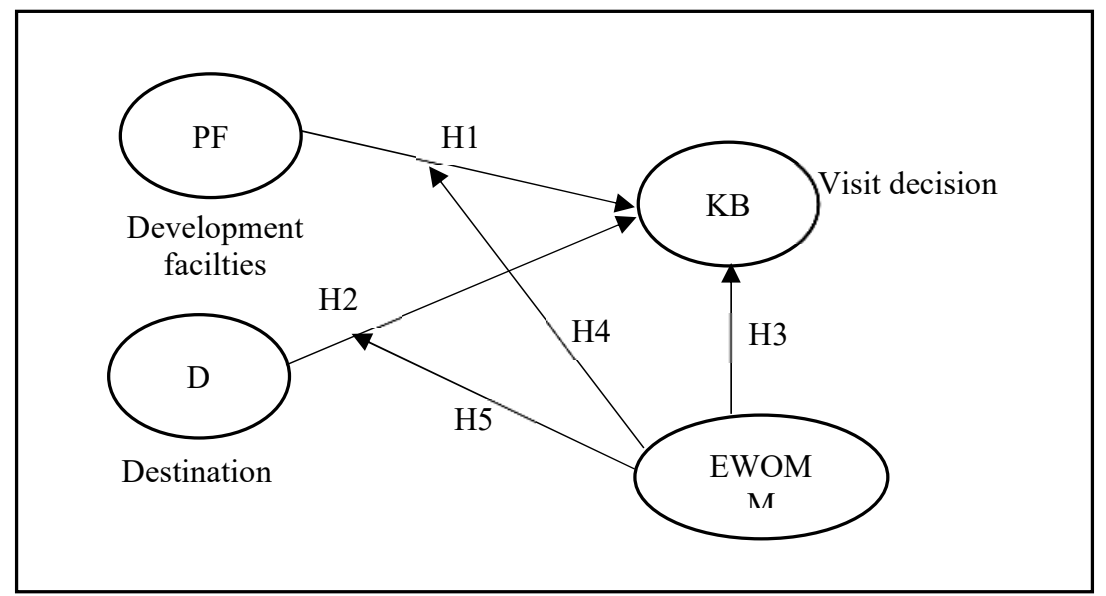

\section{RESEARCH METHOD}

This study is a causal associative study, because it analyzes the role of E-WOM as a moderation in the development of facilities and destinations on the decision of tourists visiting Pulau Perak. This research was conducted from November 2019 to May 2020.

The measurement of tourists visiting Perak Island decision variables using Ismayanti (2010), Facility Development using Edward Inskeep (1991) in (Sarim \& Wiyatna, T, 2017), Destination Attraction (Yoeti 2010) and E-WOM (A1 Hasan and Setyaningtyas, 2015). The measurement scale uses a Likert scale, with categories ranging from 1 strongly disagree, to 5 strongly agree (Sugiyono, 2009).

The population in this study were the tourists who visited the Pulau Kepulauan Pulau Seribus. With a random sampling technique, researchers distributed questionnaires to tourists vacationing in Perak Island, with a sample of 100 tourists (Hair, 2011). Methods of data analysis using Partial Least Squarae (PLS) (Ghozali and Latan, 2015). 


\section{DISCUSSION}

\section{a. Characteristics of Respondents}

Characteristics of respondents by sex, the number of female respondents is greater than male respondents. Based on age, most respondents are between 21-25 years and 26-30 years. The last education, the most high school graduates or equivalent, followed by Bachelor and Post-Graduate. Based on work, most respondents work as employees, entrepreneurs. Most respondents' income is above Rp. 5,000,000 and between Rp. 3.5,000,000 - Rp. $5,000,000$.

\section{b. Partial Least Square}

1). Evaluation of Measurement Model (outer Model)

a). Validity test

Testing validity in two ways, namely convergent validity and discriminant validity. According to Chin in Ghozali and Latan (2015) an indicator is said to have a good convergent validity if the loading factor value is greater than 0.7. The test results are shown in Figure 2. It can be seen that the loading factor value less than 0.7 is discarded, then analyzed again and the results obtained are a factor loading value greater than 0.7 .

\section{Figure 2 : convergent validity}

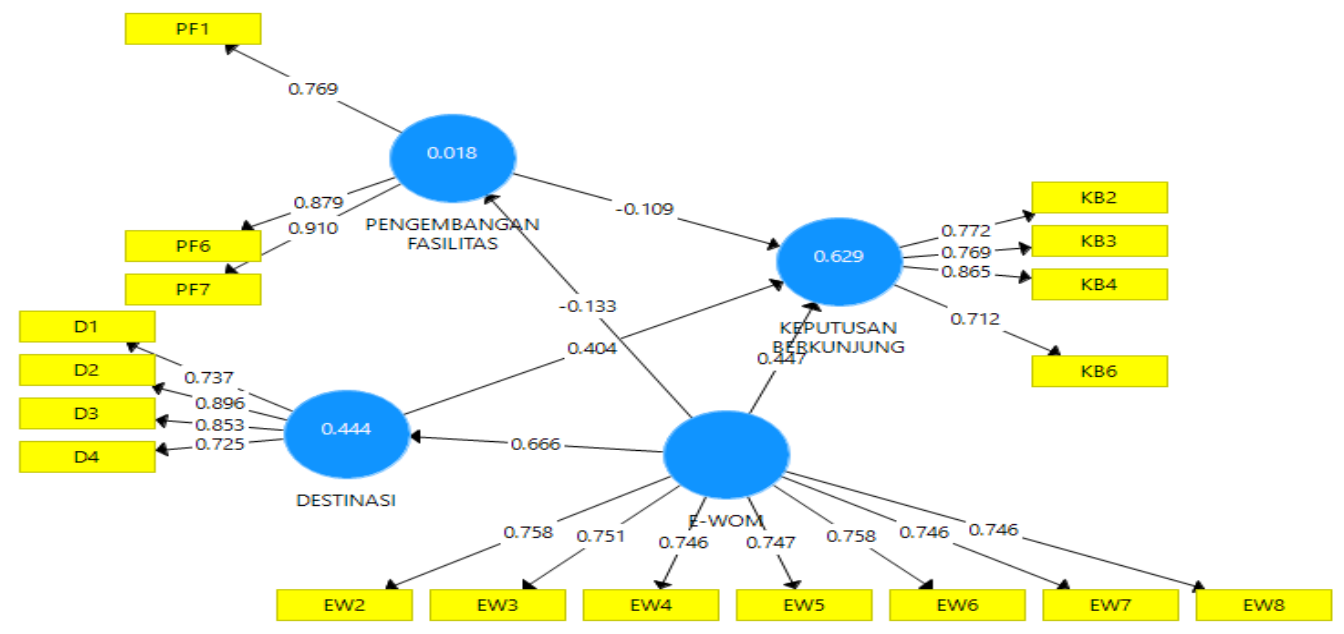

Source: Data Primer, Smart PLS, 2020

Discriminant Validity can be seen on Table1:

Table 1. Discriminant Validity

\begin{tabular}{|l|c|c|c|l|l|}
\hline & Destination & E-WOM & Visit decsion & $\begin{array}{l}\text { Moderating } \\
\text { Effect1 }\end{array}$ & $\begin{array}{l}\text { Facility } \\
\text { development }\end{array}$ \\
\hline Destination & 0,806 & & & & \\
\hline E-WOM & 0,666 & 0,750 & & & \\
\hline Visit decision & 0,703 & 0,730 & 0,782 & & \\
\hline Moderating Effect1 & $-0,417$ & $-0,528$ & $-0,359$ & 1,000 & \\
\hline $\begin{array}{l}\text { Facility } \\
\text { development }\end{array}$ & $-0,015$ & $-0,133$ & $-0,175$ & 0,046 & 0,855 \\
\hline
\end{tabular}

Source: Data Primer, Smart PLS, 2020 
Discriminate validity is analyzed by comparing the value of the square root of AVE and the correlation value between kostruk, seen in Table 1, that all square roots of each construct have a higher value than the correlation between other constructs. Thus it can be concluded that all measurement variables have good discriminant validity.

b). Reliability Test

Reliability tests were performed with Composite reliability and Cronbach Alpha. If all variable values have Composite reliability and Cronbach alpha $>0.7$, then they have good reliability or the questionnaire used is reliable or consistent. In Table 2 it can be seen that each variable has a Cronbachs Alpha value and a Composite reliability of more than 0.7 , meaning that each variable has a fairly high reliability.

Table 2. Cronbach Alpha and Composite Reliability

\begin{tabular}{|l|c|c|}
\hline \multicolumn{1}{|c|}{ Variable } & Cronbach Alpha & Composite Reliability \\
\hline Facility development & 0,818 & 0,890 \\
\hline Visit decision & 0,787 & 0,862 \\
\hline E-WOM & 0,871 & 0,900 \\
\hline Destination & 0,817 & 0,880 \\
\hline
\end{tabular}

Source: Data Primer, Smart PLS, 2020

2). Evaluation of Structural Model (Inner Model)

a). Model Accuracy Test (Goodness of Fit Model Test)

To assess the accuracy of the model test by looking at the value of R Square Adjusted. In Table 3 it can be seen that the R Square adjusted value has a low value for facility development $(0.008)$, an intermediate value for the destination $(0.438)$ and a high value for the visiting decision $(0,617)$. This shows that the facility development model has a model that is less appropriate than the destination and visiting decisions.

Table 3. Goodness fit model

\begin{tabular}{|l|c|c|}
\hline \multicolumn{1}{|c|}{ Variable } & R Square & R Square Adjusted \\
\hline Facility development & 0,018 & 0,008 \\
\hline Visit decision & 0,629 & 0,617 \\
\hline Destination & 0,444 & 0,438 \\
\hline
\end{tabular}

Source: Data Primer, Smart PLS, 2020

b). Hypothesis test

To find out the significance seen by comparing the significance value that occurs with a confidence level of 0.05 . If the significance value that occurs (indicated by the value of $\mathrm{P}$ value) $<0.05$, the hypothesis is accepted. The path coefficient results are shown in Table 4.

In Table 4, the influence of Destinations on the positive visiting decision is significant because the statistical $\mathrm{T}$ value is $3.243>1.96$ and the $\mathrm{P}$ value is $0.001<0.05$. Likewise, the effect of E-Wom on the Destination was significantly positive because the T statistic was $6.359>1.96$ and $\mathrm{P}$ values $0.000<0.05$. The influence of E-WOM on the decision of visiting was also significantly positive because the Tstatistic value of $3.710>1.96$ and Pvalues $0,000<0.05$.

While Pangaruh E-Wom on the Development of negative facilities was not significant because the original sample value was negative, the statistical $\mathrm{T}$ value was $1.349<1.96$ and the $\mathrm{P}$ value was $0.178>0.05$. Likewise, the effect of facility development on visiting decisions. In this study the moderating effect variable, E-WOM, did not influence the visiting decision. 


\begin{tabular}{|l|l|l|l|l|l|}
\hline \multicolumn{7}{|c|}{ Table 4. Hypothesis Result } \\
\hline No & \multicolumn{1}{|c|}{ Variable } & $\begin{array}{l}\text { Original } \\
\text { sample }\end{array}$ & $\begin{array}{c}\text { T } \\
\text { Statistic }\end{array}$ & $\begin{array}{c}\text { P } \\
\text { value }\end{array}$ & \multicolumn{1}{|c|}{ Remarks } \\
\hline 1 & Destination $\rightarrow$ visit decision & 0,412 & 3,243 & 0,001 & Positive Significant \\
\hline 2 & E-WOM $\rightarrow$ Destination & 0,666 & 6,359 & 0,000 & Positive Significant \\
\hline 3 & E-WOM $\rightarrow$ visit decision & 0,479 & 3,710 & 0,000 & Positive Significant \\
\hline 4 & E-WOM $\rightarrow$ facility development & $-0,133$ & 1,349 & 0,178 & $\begin{array}{l}\text { Negative, not } \\
\text { Significant }\end{array}$ \\
\hline 5 & Moderating effect1 $\rightarrow$ visit decision & 0,023 & 0,625 & 0,532 & $\begin{array}{l}\text { Positive, not } \\
\text { Significant }\end{array}$ \\
\hline 6 & $\begin{array}{l}\text { Facility development } \rightarrow \text { visit } \\
\text { development }\end{array}$ & $-0,108$ & 1,449 & 0,148 & $\begin{array}{l}\text { Negative, not } \\
\text { significant }\end{array}$ \\
\hline
\end{tabular}

Source : Data primer Smart PLS, 2020

In Figure 3 it can be seen that E-Wom has a significant effect on the Destination, then the Destination has a significant effect on the decision to visit. And E-Wom has a direct influence on the decision to visit.

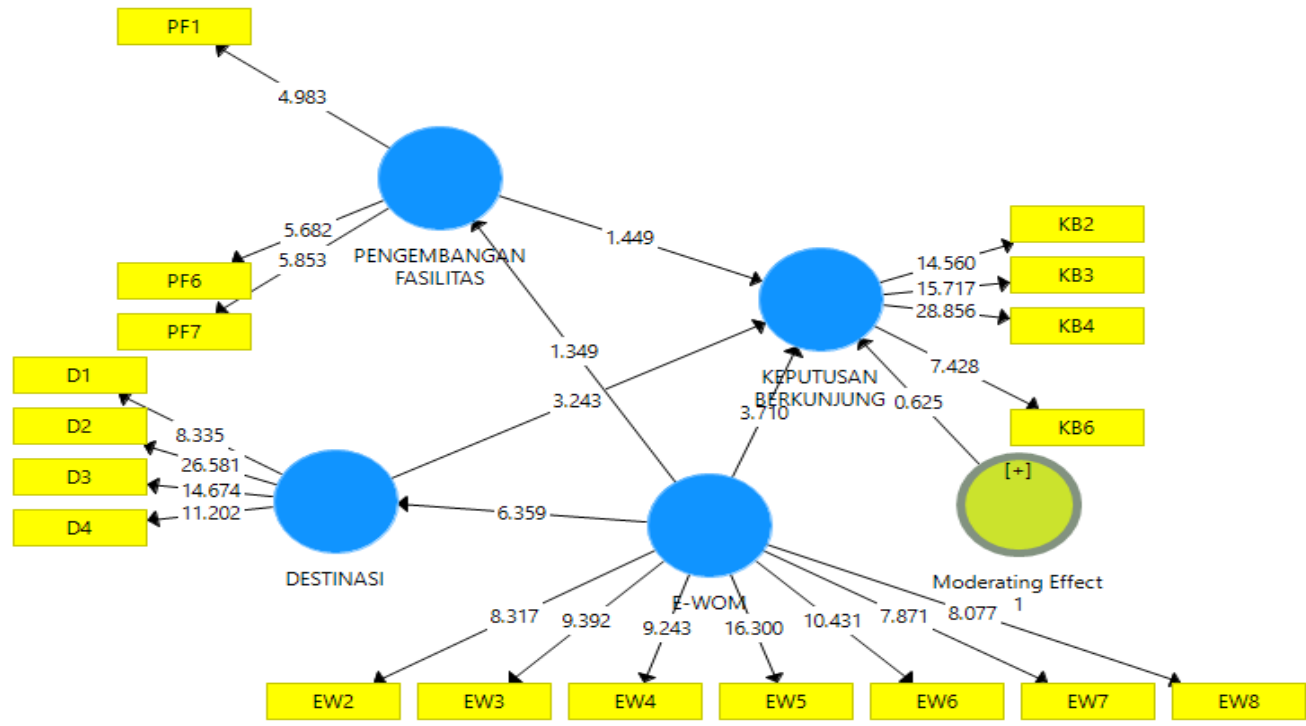

\section{c. Discussion}

1). Effect of Facility Development on Tourist Visit Decisions

Hypothesis testing results prove that hypothesis 1 was rejected, that the development of facilities had no effect on tourist visiting decisions. When analyzed using loading factors, the presence of souvenirs that characterize the tourist areas that can be purchased is the most dominant indicator in reflecting the development of facilities, apparently cannot improve tourist visiting decisions.

The results of this study reinforce previous research, Purba and Simaramta (2018) state that the culture of the community has no effect on tourist visiting decisions. But the results of this study contradict the results of the research of Astuti and Widayati (2019), Wijayanti (2012), tourist attraction factors have a positive effect on the 
interest of tourist visits and Nthebe and Seart (2017), there is a relationship between hotel employees and tourist visits. influences tourist visiting decisions.

\section{2). Influence of Destinations on Tourist Visit Decisions}

The results of hypothesis testing prove that hypothesis 2 is accepted, that the destination has a positive effect on tourist visiting decisions. When analyzed using a loading factor, there are places that must be visited by tourists and the amount of recreation that can be done is the most dominant indicator in reflecting Destinations, can improve travel destinations so as to improve tourist visiting decisions.

These results are able to be explained by Suwantoro (2014) tourist objects and attractions are grouped into 3 parts, namely 1. Natural tourism objects and attractions, 2. Cultural tourism objects and attractions 3 . Tourist objects and attractions of special interest.

The results of this study also reinforce the results of previous studies Singgih (2017), Astini and Sulistyowati (2015) stated that tourist destinations or tourist products on the beach have a positive effect on tourist visiting decisions. But the results of this study also contradict the results of previous studies, Suwarduki, et al (2016) which states that the destination is not significant to tourists visiting decisions.

\section{3). Effect of E-WoM on Tourist Visit Decisions}

Hypothesis 3 was able to be proven in this study, that E-WoM had a positive effect on tourist visiting decisions. Sense of pleasure and pride when visiting attractions and the availability of information clearly and the accuracy of information as the most powerful measurement tool in measuring E-WoM so that it is most dominant in influencing tourist visiting decisions.

This result can be explained by Wardiyastuti (2017) that E-WoM as a form of communication that develops from WoM electronically or with the use of the internet, which is better than personal selling or conventional advertising where consumers use the internet to share experiences after using products or services, or consumers can use the experience of others to make purchases.

The results of this study also reinforce previous research, Wahyuningtiyas (2018) states E-WoM affects the decision of visiting tourists. But the results of this study also contradict the results of previous studies Suwarduki, et al (2016), E-WoM is not significant on tourist visiting decisions.

\section{4). Effect of E-WoM Can Enhance Facility Development against Tourist Visiting Decisions}

The results of hypothesis testing prove that hypothesis 4 is rejected, that E-WoM has no effect on the development of facilities so it has no effect on tourist visiting decisions. When analyzed using loading factors, there is a sense of pleasure and pride when visiting attractions and the availability of information clearly and the accuracy of information is the most dominant indicator in reflecting E-WoM, apparently can not improve tourist visiting decisions because it cannot improve the development of facilities as they are by -oleh / souvenir which is characteristic of tourist areas that can be bought by tourists.

According to Gruen (2006) electronic Word of Mouth (e-WoM) is a communication medium for sharing information about a product or service that has been consumed by consumers who do not know each other and meet before.

The results of this study contradict the research of Suharyono and Kusmadji (2016), that E-WoM has a positive effect on increasing consumer confidence about the information provided, positively influencing purchase intentions and purchasing decisions / tourist visiting decisions. Likewise, the results of Mahaputra and Setiawan's research (2019), that E-WoM had a significant positive effect on consumer visiting decisions / tourist visiting decisions.

\section{5). Effect of E-WoM Can Increase Destinations Against Tourist Visiting Decisions}

The results of hypothesis testing prove that hypothesis 5 is accepted, that E-WoM can men $n$ increase destinations and positively influence tourist visiting decisions. When analyzed using a loading factor, there are places that must be visited by tourists and the amount of recreation that can be done is the most dominant indicator in reflecting Destinations, so that it can improve travel destinations and can improve tourist visiting decisions. When analyzed using loading factors, the presence of pleasure and pride when visiting a tourist attraction and the availability of 
information clearly and the accuracy of information is the most dominant indicator in reflecting E-WoM, in fact it can increase the destination of recreational places that must be visited and the amount of recreation that can be done, so as to improve the Travel Destinations for Tourist visiting Decisions.

This can be explained by Kamtarin (2012), that the dissemination of information through EWOM is done through online media or the internet such as through email, blogs, chat rooms, Facebook, Twitter and various other types of social media that can cause interactions between consumers and other consumers, the existence of online social communication will automatically be able to help consumers share experiences about the products or services they have obtained in the purchasing process, in the form of a tourist visiting decision.

The results of this study also reinforce the results of previous research by Putra (2019) which states that E-WoM can increase the destination of tourist satisfaction that affects tourist visiting decisions. Also supporting research Illah et al (2019), which states that the destination image and electronic word of mouth and consumer perceptions significantly influence the decision of tourists visiting tourist attractions.

The summary of the results of the discussion above (Figure 3 Bootstrapping Results), shows that E-WoM can increase the Destination of the Tourist Visiting decision (H5 and H2 Significant), as well as E-WoM directly influence the tourist visiting decision (H3 significant). But E-WoM cannot improve the development of facilities on tourist visiting decisions (H4 and $\mathrm{H} 1$ are not significant). So E-WoM as a Moderating Effect variable cannot improve tourist visiting decisions

\section{CONCLUSIONS AND SUGGESTIONS}

a). Conclusion

Based on the previous description, it can be concluded that the Destination has a positive effect on tourist visiting decisions. E-WOM has a positive effect on tourist visiting decisions. E-WOM can improve destinations and positively influence tourist visiting decisions. E-WOM cannot improve the development of facilities on tourist visiting decisions. The development of facilities has no effect on tourist visiting decisions.

b). Suggestion

Based on the discussion and conclusions it can be suggested that to add places that must be visited by tourists and the amount of recreation that tourists can do, this is the most dominant indicator in reflecting the Destination so that it can improve tourist visiting decisions.

Increasing tourist objects and the availability of information clearly and the accuracy of information as the most powerful measurement tool in measuring E-WoM so as to increase tourist visiting decisions. Also increase the diversity of regional culture, souvenirs typical of the area so that tourists feel happy and proud when visiting tourist attractions

Suggestions for further researchers, so that more research is done on tourism in addition to tourist destinations, facility development and E-WoM, so that the world of tourism in Indonesia is more advanced.

Our gratitude goes to the Chancellor of Mercu Buana University, Jakarta and his staff who have given us the opportunity to carry out KDN research. Also the Chairperson of the Trisakti School of Management and his staff for their cooperation in this research.

\section{References}

Abdila, R. (2015). Pulau Perak, Thousand Islands: No Occupants, here you are like a Vacation on a Private Island. Downloaded from : http://m.tribunnews.com/amp/travel/2015/08/25/pulau-perak-kepulauanseribu-tak-ada-penghuni-di-sini-anda-bak-berlibur-di-pulau- pribadi?page=3. Pada 25 Agustus 2015 .

Abubakar, A.M (2016). Does eWOM Influence Destination Trust and Travel Intention : A Medical Tourism Perspective. Journal Economic Research 29(1) : 598 - 611

Abubakar, A.M et all.(2017). eWOM, Revisit Intention, Destination Trust and Gender. Journal of Hospitality and Tourism Management 31(2017): 220-227

Albaraq \& Abas, N. (2014). Measuring the Impacts of Online Word of Mouth on Tourists' Attitude and Intentions to Visit Jordan: An Empirical Study.International Bussiness Research, 7 (1).

Alpiah, D (2019). The Influence of Facilities Development and Tourism Attraction of Perak Island on Tourism Visit Interests. Bachelor Thesis Management Department, Faculty of Business Economics, Universitas Mercu Buana Jakarta.

Ambarwati, P (2019). Effect of Destination Attractiveness on Tourist Visit Decisions With E-WoM as Mediation Variables. Bachelor Thesis, Department of Management, Faculty of Economics Universitas Mercu Buana Jakarta. 
Ariani, Z.R and Wandebori,H (2016). The Influence of Product Attributes of Tourism and Electronik Word of Mouth (eWOM) on the Decision to Visit Parang IJO Waterfallin Karanganyar Region Centra Java. Journal of Marketing Research 43 ( 3) : $1-25$

Astini, R and Sulistiyowati, I (2015). The Effect of Destination Image, Travel Mutivation and Service Quality on Visitor Satisfaction (Case Study on Muslim Archipelago Travelers at Carita Pandeglang Beach, Banten, Scientific Journal of Management and Business, 1 (3): 1-10

Astuti,Y and Widayati,C (2019). The Natural Resources Governance as a Moderation for the Effect of Natural Environment on Community Based Empowerment (Case study in Ringgung Beach Bandar Lampung). Journal of Economics and Sustainable Development, 10 (18) : 100 - 106

Central Statistics Agency (BPS).(2018). Kecamatan Kepualaun Seribu Utara in number 2018. Katalog BPS 11020013101 diakses dari: http://kepulauanseribu.kab. bps.go.id.

Boley and Green (2016). Ecotourism and Natural Resource Conservation. The "Potential" for a Suatainable Symbiotic relationship. Journal of Ecotourism. $15: 36-50$.

Devesa, M; Laguna, M; dan Palacios, A ( 2010 ). The role of motivation in visitor satisfaction: Empirical evidence in rural tourism. Tourism Management, 31 (4) : 547 - 552

Fang Meng, Yodmanee Tepanon, Muzaffer Uysal ( 2008 ). Measuring tourist satisfaction by attribute and motivation: The case of a nature-based resort. Journal of Vacation Marketing, 14 (1) : 1 - 8

Ghozali, I dan Latan, H (2015). Partrial Least Squares. Concepts, Techniques and Applications Using the Smart PLS 3.0 Program. Issue 2. Publisher Agency Universitas Diponegoro Semarang.

Gruen, T., Osmonbekov, T., Czaplewski. A. (2006). e-WoM: the impact of customer-to-customer online know how exchange on customer value and loyalty. Journal of Business Research. 59(4).226-235.

Hasan, A., Setyaningtyas, W. (2015). The influence of Word of Mouth Electronics on Facebook's social media on the decision of tourists visiting tourist villages Nglanggeran Gunung Kidul. Journal of Tourism Media.13 (1). 224-238.

Hair, J., Black, Jr., Babin, Bj., \& Anderson, Re. (2011). Multivariate Data Analysis. Seventh edition. Prencite Hall. Upper Saddle River.

Illah, A, N; Sularso, R. A dan Irawan, B (2019). The Influence of Destination and E-WoM Images on Instagram Social Media and Consumer Perception of the Decision to Visit B29 Tourism Object in Lumajang Regency. e-Journal Ekonomi Bisnis dan Akuntansi, VI (1 ) : 164 - 170.

Ismayanti. (2010). Introduction to tourism, PT. Grasindo. Jakarta.

Kamtarin, M. (2012). The effect of Electronic Word of Mouth, Trust and Perceived Value on Behavioral Intention from the Perspective of Consumers. International Journal of Academic Research in Economics and Management Sciences ( 1 ) 4.

Kotler (2000). Marketing Management in Indonesia Planning, Implementation and Control Analysis. Translated by A.B Susanto. Fourth Edition, Jakarta.

Mahaputra,D,G,K dan Setiawan, P, Y ( 2019). The Role of Attitude Mediates the Effect of Electronic Word of Mouth on Visiting Decisions. E-Jurnal Management, 8(12) : 7326 - 7348.

Nachyun (Paul) Jin , Sangmook Lee, Hyuckgi Lee (2015). The Effect of Experience Quality on Perceived Value, Satisfaction, Image and Behavioral Intention of Water Park Patrons: New versus Repeat Visito. International Journal of Tourism Research, 17 ( 1 ) : 82 - 95

Nowacki, M,M (2009). Quality of visitor attractions, satisfaction, benefits and behavioura intentions of visitors: verification of a model. International Journal of Tourism Research, 11 ( 3 ) : 297 - 309

Prayogo, R (2016). Asian pacific Management and business. Journal, 5(2) 2016

Pulau Perak Thousand Islands (2015). Piece of Silver Island Beauty. Downloaded from http://www.pulauperak.com/2015/12/sepenggal-keindahan- pulau-perak-by.html. Pada 13 November 2018.

Purba, M, L dan Simaramta, G (2018). Effect of Service Quality and Culture on Attraction and Interest in Visiting Percut Tourism. Journal of Business and Management Concepts, 5 (1).

Putra, S.P.A.M ( 2019 ). Effect of E-WoM on Destination Image, Satisfaction and Loyalty. (Study on tourist visits to DIY). Modus Journal. 29 (2): 201-218

QingChi,C,G and HailinAu ( 2018 ). Examining the structural relationships of destination image, tourist satisfaction and destination loyalty: An integrated approach. Tourism Management, 29 ( 4 ) : $624-636$

Rizal, H., Yussof, S., Amin, H. and Chen-Jung, K. (2018), "EWOM towards homestays lodging: extending the information system success model". Journal of Hospitality and Tourism Technology, 9(1) : 94-108.

Sarim \& Wiyana, T. (2017). Effect of Tourist Facilities on Tourist Visit Motivation (Case Study of Solo Tourist Visits). Journal of Hospitality and Tourism, 3(2), 294-374 
Singgih, N (2017). Effects of Tourism Products and Electronic Word Of Mouth Against Visiting Decision. Journal of Economics, 3 (2). 1-9.

Sugiyono. (2014). Management Research Methods. Second Edition, Alfabeta. Bandung

Suharyono, S, Z dan Kumaji, S. 2016. The Effect of Electronicword of Mouth Communication on Trust and Purchase Intention and Its Impact on Purchasing Decisions (Survey on Online Shopping Consumer Zafertech.Com). Journal of Business and Management,3 ( 1 ) : $65-71$

SunnySun, RobLaw, Markus Schuckert ( 2019 ). Mediating effects of attitude, subjective norms and perceived behavioural control for mobile payment-based hotel reservations. International Journal of Hospitality Management, $84: 1-8$

Suwantoro, (2014). Effects of Tourist Attractions and Tourist Motivation on Decision to Visit. Journal of Business Administration (JAB), 42(2), 4.

Suwarduki. (2016). Analysis of the EWOM-forming factors and their effects towards buying interest. Journal of Business Administration, 37 (2). 13-20.

Wahyuningtiyas, N. (2018). Analysis of the factors that influence the desire and decision to visit the beach and its implications for Willingness To Recommendation. Journal of Management Science, 3 (1). 79-92.

Wardiyastuti, D. (2017). The effect of electronic word of mouth on consumer buying interest through brands (a study of wedanganradjiman's Instagram followers as potential customers). Faculty of Islamic Economics and Business, Surakarta State Islamic Institute.

Wartini, N.N.A.dkk.2018. Analysis of Factors Affecting the Intention of the Tourist Return Visit to Tourism Attraction in Bandung District

Wijayanti. A (2012). The Influence of Internal and External Environments on the Interest of Tourist Visits Through the Tourism Attraction of Tirta Arta Park in Sleman Regency Yogyakarta. Journal of Knowledge, 3 (1).

Yoeti, O.A. (2010). Planning Strategies for Tourist Destination Areas. First edition, Pradaya Paramita. Jakarta.

Zabkar, V, Brencic, M.M dan Dmitrovic, T. ( 2010 ). Modelling perceived quality, visitor satisfaction and behavioural intentions at the destination level. Tourism Management, 31 (4) : 537 - 546 